Article

\title{
Bioclimatic Extremes Drive Forest Mortality in Southwest, Western Australia
}

\section{Bradley John Evans ${ }^{1,2}, *$ and Tom Lyons ${ }^{2}$}

1 Macquarie University, Department of Biological Sciences, University Avenue, Macquarie Park, New South Wales 2113, Australia

2 Centre of Excellence for Climate Change, Woodland and Forest Health, Murdoch University, 90 South Street, Murdoch, Western Australia 6150, Australia; E-Mail: T.Lyons@murdoch.edu.au

* Author to whom correspondence should be addressed; E-Mail: Brad.Evans@mq.edu.au; Tel.: +61-438-123-438.

Received: 12 March 2013; in revised form: 24 June 2013 / Accepted: 27 June 2013 /

Published: 8 July 2013

\begin{abstract}
Extreme and persistent reductions in annual precipitation and an increase in the mean diurnal temperature range have resulted in patch scale forest mortality following the summer of 2010-2011 within the Forest study area near Perth, Western Australia. The impacts of 20 bioclimatic indicators derived from temperature, precipitation and of actual and potential evapotranspiration are quantified. We found that spatially aggregated seasonal climatologies across the study area show 2011 with an annual mean of $17.7^{\circ} \mathrm{C}\left( \pm 5.3^{\circ} \mathrm{C}\right)$ was $1.1{ }^{\circ} \mathrm{C}$ warmer than the mean over recent decades (1981-2011,$16.6^{\circ} \mathrm{C} \pm 4.6{ }^{\circ} \mathrm{C}$ ) and the mean has been increasing over the last decade. Compared to the same period, 2010-2011 summer maximum temperatures were $1.4{ }^{\circ} \mathrm{C}\left(31.6{ }^{\circ} \mathrm{C} \pm 2.0{ }^{\circ} \mathrm{C}\right)$ higher and the annual mean diurnal temperature range $\left(\mathrm{T}_{\max }-\mathrm{T}_{\min }\right)$ was $1.6{ }^{\circ} \mathrm{C}$ higher $\left(14.7^{\circ} \mathrm{C} \pm 0.5^{\circ} \mathrm{C}\right)$. In 2009 , the year before the forest mortality began, annual precipitation across the study area was $69 \%$ less $(301 \mathrm{~mm} \pm 38 \mathrm{~mm})$ than the mean of 1981-2010 (907 mm $\pm 69 \mathrm{~mm}$ ). Using Système Pour l'Observation de la Terre mission 5 (SPOT-5) satellite imagery captured after the summer of 2010-2011 we map a broad scale forest mortality event across the Forested study area. This satellite-climatology based methodology provides a means of monitoring and mapping similar forest mortality eventsa critical contribution to our understanding the dynamical bioclimatic drivers of forest mortality events.
\end{abstract}


Keywords: bioclimatic extremes; forest mortality; SPOT-5; Moderate Resolution Imaging Spectroradiometer (MODIS); climatologies

\section{Introduction}

Regional drought and heat stress over the past 30 years has resulted in climate-driven forest and woodland mortality events globally [1]. Forests and woodlands that cannot relocate to suitable climatic conditions face a reduction of range, fragmentation, mortality and in extreme cases extinction [2]. The warming and drying of Mediterranean biomes increases their vulnerability [3-6] by reducing water availability and increasing vegetation stress and the frequency of mortality [7]. Growing evidence suggests that as climates dry and warm the risks of biodiversity loss [8] and severe wildfires increase [9]. Such dramatic landscape scale transformations are not likely to occur rapidly, rather evolve as a response to abiotic [10] and biotic changes and the signs of change are already beginning to emerge [1,11]. As with other Mediterranean climates, the vegetation of southwest Western Australia (SWWA) is threatened by these changes.

Figure 1. Map featuring the study area and the Interim Biogeographical Region of Australia's NJF and SCP surrounding Perth.

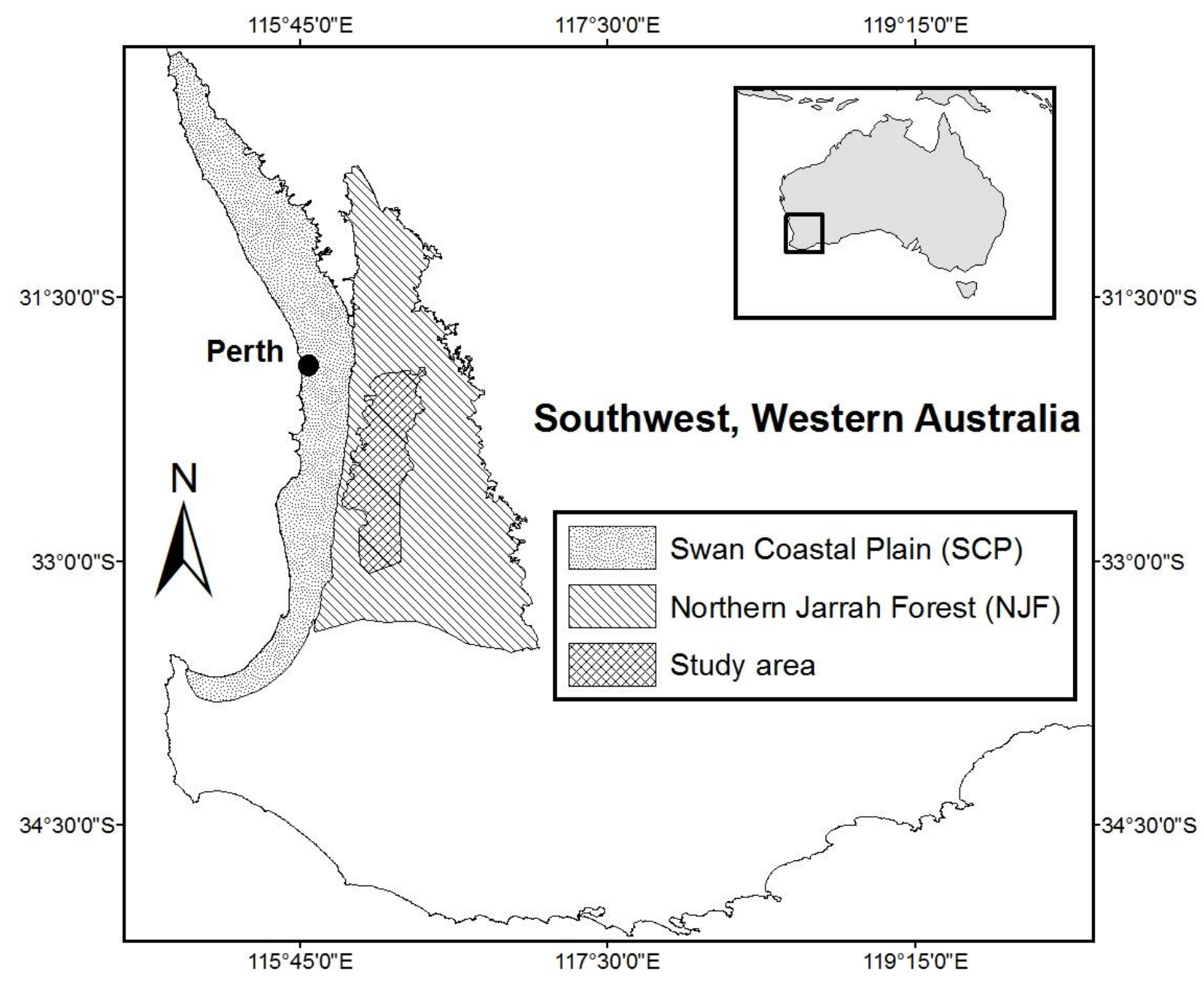


Declines of this kind are not new to the SWWA, for example the declines of the tuart forest (Eucalyptus gomphocephala) on the Swan Coastal Plain (SCP) (refer to Figure 1) in the late 1990s and 2000s [12-14]. Over the last decade, severe drought has impacted on the climate of southern [15] and southwest Australia resulting in marked declines in forest and woodland condition [16,17]. Since the 1970's the southwest has received 15-20\% less than average rainfall [17] and a $0.4{ }^{\circ} \mathrm{C}$ degree increase in temperature [18] leading to the marked depletion of stream flow through the forested region surrounding Perth [10,17] known as the Northern Jarrah (Eucalyptus marginata) Forest (NJF). For example, Petrone [17] shows that a reduction in the average streamflow in the NJF region (calculated as pre-1989 and post-2008 changes) range between $-39 \%$ and $-78 \%$ across the catchments monitoring sites. Petrone [17] also shows that, in the region surrounding the NJF, potential evaporation often exceeds precipitation and only a small portion (3-20\%) of runoff is generated directly from rainfall and groundwater levels have been consistently falling [19]. Experimental results [10] suggest that reductions in forest cover would result in increased streamflow and silvicultural forest canopy thinning has been used as a solution for increasing streamflow into drinking water catchments in the NJF.

In the context of forest distribution and health, bioclimatic limits (or thresholds) define how the forest is affected by its climate. A bioclimatic limit of the distribution of the Jarrah forest was first proposed by Gentilli [20]. At the time, the SCP received around $300 \mathrm{~mm}$ less annual rainfall (850 $\mathrm{mm}$ ) than the Jarrah forest $(1100 \mathrm{~mm})$ which includes the NJF. Gentilli [20] estimated that this restricted the Jarrah forests westward expansion towards the SCP on the basis of precipitation and evaporative demand: he defined the forest-sustaining bioclimatic threshold to be $800 \mathrm{~mm}$ of rain per annum and showed that a difference from the mean of $165 \mathrm{~mm}$ rainfall per annum would be significant to drive changes in the forests distribution across SWWA.

A severe inter-annual change in precipitation of the order of that described by Gentilli [20] came to the region between 2009 and 2011. Specifically, nil rainfall was recorded for 122 days at Perth Airport between 21 November 2009 and 22 March 2010 [21]. Additionally, the state area average temperature for summer 2009-2010 was equal highest on record, $1.5{ }^{\circ} \mathrm{C}$ above average at $36.7{ }^{\circ} \mathrm{C}$ [21]. Autumn (March, April and May 2010) temperatures were the sixth warmest on record at $1.4{ }^{\circ} \mathrm{C}$ above the long term of state area average of $31.1^{\circ} \mathrm{C}$ [22]. Furthermore, winter 2010 (June, July and August) was the driest and third coldest on record in the southwest [23]. The record winter cold and dry spell was followed by the fifth warmest average summer on record, spatially estimated to be $+1.09{ }^{\circ} \mathrm{C}$ above the states long term average [23].

Recently, the Bureau of Meteorology (2012) noted that the prolonged dry spell through summer 2010-2011 contributed to a series of out-of-control forest fires, in the presence of an abundance of dryfuel, resulted in over 100 homes being destroyed or damaged. Extreme fire events such as these are not unprecedented yet are uncommon and formative in that they illustrate the threat posed by dry vegetation and hot conditions. It is critical to record and understand the spatial and temporal dynamics of these events [24]. It is expected that Mediterranean ecosystems will experience more frequent and prolonged climatic variability [25] and the need to understand the spatial extent and consequences of these impacts is central to the success of our adaptation strategies in the long term.

In regions where clear evidence of bioclimatic change is taking place, it is critical to develop suitable methodologies to record the extent and severity of forest and woodland mortality events and to quantify the bioclimatic-dynamics in order to understand the difference between natural variability and 
change. The only tool for achieving near real time, contiguous landscape and continental scale monitoring is remote sensing. Detection of eucalypt canopy dieback using high spatial resolution remote sensing imagery has been shown by a large number of authors and typically involves using spectral bands focused on chlorophyll pigments of the foliage, leaf structural attributes and defoliation [26-32]. Moderate resolution satellite remote sensing (e.g., $250 \mathrm{~m}-5 \mathrm{~km}$ ) has been shown to be useful in detecting abrupt changes in greenness and cover [33-35] by extracting a noiseless trend from the raw data once seasonal and high frequency changes are removed [36]. Using remote sensing to map in combination with gridded and modeled climatologies [8,37] can provide insight into the temporal and spatial dynamics of forested ecosystems.

The objectives of this study were, firstly to use remote sensing technology to map the extent of "patches of mortality“ (POM) resulting from the extreme weather of 2010-2011. Secondly, once spatially mapped, we analyze the bioclimatic conditions preceding the event and identify the underlying drivers of the forest mortality. We conclude with a number of potential future research directions on employing this methodology for understanding the responses of the forest stands to changing climatic conditions.

\section{Methods}

\subsection{Overview}

Following a severe mortality event (July 2011) the methodology for this manuscript was designed to map and investigate the drivers behind the declines. This involved establishing twenty field sites located across the forest, which a team of forest pathologists established and began monitoring immediately [38]. Simultaneously, Système Pour l'Observation de la Terre mission 5 (SPOT-5) Satellite imagery was acquired from PlanetAction.org and a feature extraction model, based on known biophysical relationships of remotely sensed imagery, was developed using the field sites with the aim of identifying POM across the imagery. An independent model evaluation dataset was used on the POM identified by the model. Bioclimatic space and time series analysis of Australian Water Availability Data (AWAP) [39] and Moderate Resolution Imaging Spectroradiometer (MODIS) Fractional Cover were used to evaluate the environmental envelope of the study area. Spatially and temporally averaged statistics are evaluated over the period 1981-2011, hereafter the 30 year study period.

\subsection{Study Area}

The NJF directly east of Perth, Western Australia (Figure 1) has a Mediterranean climate, hot, dry summers and wet winters and has a history of tree declines [40]. The NJF is classified as a medium open forest of average height between 10-30 m with canopy cover between 30-70\% that lies atop the Darling Plateau on a substrate of archaen granite and metamorphic rocks with an average elevation of $300 \mathrm{~m}$ above sea level [41,42]. Rainfall varies from around $1000 \mathrm{~mm}$ on the western side of the scarp to $400 \mathrm{~mm}$ to the northern and eastern extremes [42]. The region serves as the main surface water supply for Perth as the Swan, Helena, Canning, Serpentine and Murray rivers flow off the Darling Plateau onto the SCP below [17]. 
The soils vary from lateric gravels to clay and the dominant plant species, Eucalyptus marginata (Jarrah) are distributed in a mosaic across the western side and a mix of species dominate the eastern area with Jarrah co-occurring with Corymbia calophylla. The mid-storey consists of a mix of Banksia grandis, Allocasuarina fraseriana, Persoonia longifolia, Xanthorrhoea preissii and the shrub layer is comprised of a variety of perennial woody species. Across the region this topographical variability, granite substrate and gravel soils serve for rapid changes in floristic distribution from the winter water logged valley floors (drains) to the rocky granite outcrops (uplands).

The NJF is extensively mined for bauxite used in aluminum production, coal and other resources. Over the last three decades considerable emphasis has been placed on restoration of dormant mining sites throughout the forest. A post-mining re-vegetation prescription of 2,500-10,000 stems/ ha is used and designed to produce 350 stems/ha after 12 years of rehabilitation under the caveat that the sites are managed and thinned to this prescription [43]. Land use across the forest is thus a mosaic of mining, nature reserves, commercial forestry with areas set aside for Perth's water catchment.

\subsection{Field Data for Model Development}

In July 2011, patches containing mortality were located within the NJF by a team of forest pathologists on a number of field visits. The patches used in this study varied in size from 3,720 to $168,152 \mathrm{~m}^{2}$ and a complete inventory of the work can be found in Matusick et al. [38]. The objective of the field work was not to identify all patches in a region, rather identify a number of sites for detailed investigation of the causes [38] and ultimately to use these for detecting and modeling the landscape scale of the POM in this study. Generally, the sites identified for use in this study were easily identifiable from high-ground and from the road whilst travelling through the forest. Twenty of these plots were located using differential Global Positioning System (dGPS) representing a range of dieback classes. Patches of healthy and dead trees were then delineated using dGPS by trained forest health professionals and a range of indices (not used in this study) were used to determine both the healthy and dead class.

\subsection{Airborne Imagery for Validation of the Model}

To obtain additional information on the extent of the tree mortality across the forest Digital Multi-Spectral Imagery (DMSI) had been acquired by SpecTerra Services (Perth, Western Australia) over small sections of the NJF as part of ongoing research into the hydrology of the forest (Batini personal communications 2011) on the $18^{\text {th }}$ of November 2010. This imagery provided a clear indication of foliage cover and a means to compare geographical features in the imagery to field made records of the presence and absence of decline since the imagery was taken when the forest did not contain any POM. A $1 \mathrm{~km} \times 1 \mathrm{~km}$ grid (refer to Figure 2(b).) was overlaid the imagery and a forest health assessment expert classified where POM were known to have occurred intersecting each grid point as either healthy or containing mortality following the summer of 2010-2011. [44] was used for this exercise. This resulted in a validation area covering $135 \mathrm{~km}^{2}$ of the NJF. These pixels were then aggregated to produce a confusion matrix of pixels containing greater than $60 \%$ mortality and those containing less than $40 \%$ mortality, therefore considered healthy. 
Figure 2. Système Pour l'Observation de la Terre mission 5 (SPOT-5) infrared imagery $(10 \mathrm{~m})$ overlaid with (a) field data and feature extraction modeled patches of mortality (POM) and (b) the model evaluation grid and POM contained within a number of cells.
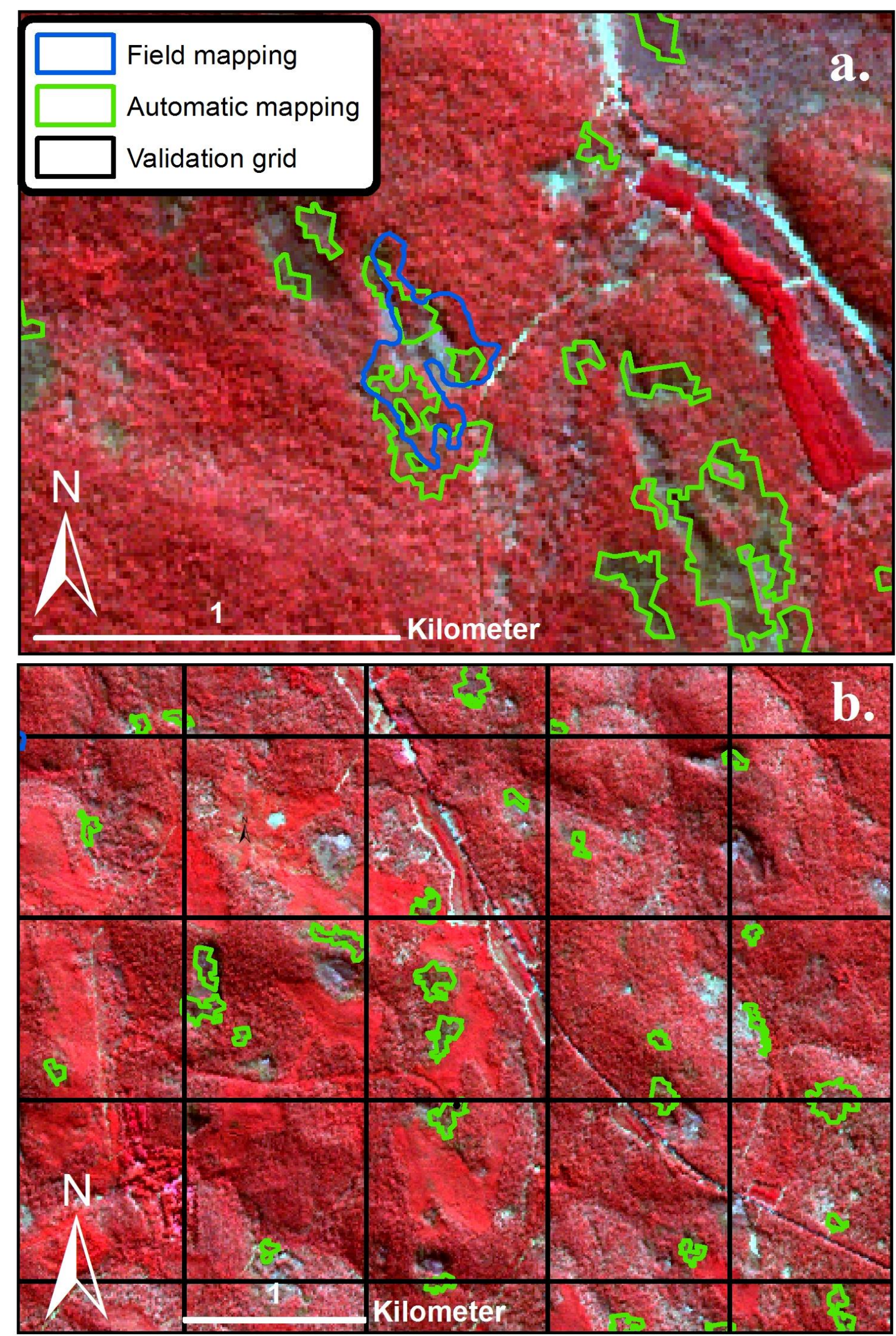


\subsection{SPOT-5 Satellite Imagery}

SPOT-5 satellite imagery was acquired across a large section of the forest on $29^{\text {th }}$ June, 2011 and $14^{\text {th }}$ July 2011 before the first winter rains in order to determine the extent of vegetation declines across the region. The SPOT-5 imagery used was $10 \mathrm{~m}$ spatial resolution with four spectral bands green ( 500 to $590 \mathrm{~nm}$ ), red ( 610 to $680 \mathrm{~nm}$ ), near-infrared ( 790 to $890 \mathrm{~nm}$ ) and shortwave-infrared $(1,580$ to $1,750 \mathrm{~nm})$. The four scenes used to cover the region came with radiometric correction of viewing angle and sensor related distortions in preprocessing level 1A [45]. Imagery was orthorectified and converted to surface reflectance.

\subsection{Feature Extraction Model Development}

Since, the $10 \mathrm{~m}$ SPOT-5 imagery was insufficient to see individual crowns an object based 'feature extraction' approach was developed to identify POM across the study area located within NJF [46]. Feature extraction was selected because the sites varied in size, structure and landscape position. Feature extraction involves first delineating areas of similar spectral and textural likeness by manipulating only spatial parameters, thus creating a mosaic of landscape features of similar spectral and textural likeness. The second step was to extract the features of interest (i.e., the POM) by classifying them by their spatial, textural and radiometric properties, however, given the distinct differences between healthy, green forest and the POM, only radiometric and spatial properties were needed.

Three simple rules were identified by the object based image analysis systems to distinguish POM across the otherwise healthy forest; (1) the mean of ratio of the near infra-red and red bands (i.e., mean patch greenness) of the imagery being less than 0.83 (unit less) was identified as a suitable threshold in a histogram analysis of agreement with the field data. (2) The POM size being between $5,000 \mathrm{~m}^{2}$, the Food and Agriculture Organization (FAO) [47] definition of a minimum forest patch size and the upper size limit of $325,000 \mathrm{~m}^{2}$ being twice the size of the limited area field data and representative of POM identified across the entire study area. (3) The mean of the green band was zero, indicative of non-photosynthetic vegetation and the absence of greenness, thus complementing rule 1.

Using these three rules, the model was visually calibrated on the 20 healthy and 20 mortality field sites identified and resulted in a total of $n=1,853$ POM across the study area. The accuracy of the object based classification was then assessed by comparing a $135 \mathrm{~km}^{2}$ forest health assessment grid of $1 \mathrm{~km}^{2}$ cells with the classified objects in a standard confusion matrix allowing overall, user and producers' accuracy to be calculated.

\subsection{MODIS Fractional Cover Dataset}

We use the MODIS-based vegetation fractional (MODFC) cover dataset developed by Guerschman [33] to determine changes in fractional cover between 2000 and 2012 in order to establish the natural variability experienced by the forest against which we compare the impact of the 2010-2011 event. MODFC was selected because it has been used for national monitoring of ground cover [48] and is currently the only estimate of photosynthetic vegetation $\left(f_{p v}\right)$, non-photosyntheic vegetation $\left(f_{\text {npv }}\right)$ and bare soil $\left(f_{b s}\right)$ data validated for Australia. We address the issue of spatial and temporal disparity between remotely sensed greenness (SPOT-5 at $10 \mathrm{~m}$ ), cover observations 
(MODFC $0.5 \mathrm{~km}$ ) and climatologies by aggregating the fractional cover from its native resolution down to that of the climatologies used in our bioclimatic analyses and specifically for comparison across scale. In order to determine significant trends versus signal noise we use the Seasonal Trend Decomposition using Loess (STL) package in the R-Project framework after Cleveland et al. [36].

The STL method provides a loess smoothed trend by calculating and extracting a seasonal cycle and high frequency variability and subtracting these components from the raw $\mathrm{f}_{\mathrm{pv}}, \mathrm{f}_{\mathrm{npv}}$ and $\mathrm{f}_{\mathrm{bs}}$ signal. The resulting trend can then be used to reliably determine significant trends (i.e., positive or negative departures) from the time series mean (M) and standard deviation (SD). We define a significantly positive trend as being when the loess trend is greater than the sum of $\mathrm{M}$ and SD, for example, a significant growth trend is said to occur when $\mathrm{f}_{\mathrm{pv}}$ is greater than the sum of the M and SD (MSD) and a significant decline in cover when $\mathrm{f}_{\mathrm{pv}}$ is less than MSD. Additionally, we calculate a rolling M and SD for the raw data using a moving window of three months. This provides an estimate of the local variance of the SD of the raw data relative to the STL trend, useful for visually assessing the temporal variance in both the raw and trend signals simultaneously.

\subsection{Gridded Climatologies and Bioclimate Analysis}

The AWAP dataset [39] was used because it is recognised as an accurate resource of the state and trends of the terrestrial water balance of the Australian continent at a spatial resolution of 0.05 degrees (nominally $5 \mathrm{~km}$ ) [49]. Monthly climatologies of minimum and maximum temperature, precipitation, actual (total) evaporation and potential evaporation were spatially extracted from AWAP for the study period. Spatially explicit climatologies of the study area and the NJF were then aggregated for the analysis across seasonal and inter-annual timescales necessary to understand the climatic envelope of the forested study area.

In the NJF, subsurface through-flows are coupled to soil moisture recharge [10] and there is an annual moisture deficit [17] consistent with a Mediterranean climate [50]. The net result is that wet season (winter) precipitation that is not intercepted or stored is lost to runoff and stream flow. In addressing this issue for similar climates, Prentice et al. [50] proposed a scalar, $\alpha$ renamed to the Mean Annual Aridity Index (MAAI) for this study, designed to capture the seasonal variability of soil moisture independently of vegetation interception and considered it indicative of the growth-limiting drought stress on vegetation.

We calculate the MAAI as the ratio of actual (total) evaporation $\left(E_{a}\right)$ to potential evaporation $\left(E_{p}\right)$ derived from the AWAP climatologies [39] which models evapotranspiration approximate to the methods of Priestley and Taylor [51]. We assume that actual evapotranspiration $\left(\mathrm{E}_{\mathrm{a}}\right)$ can never be greater than potential evapotranspiration $\left(E_{p}\right)$ and that $E_{a}$ constrains both soil evaporation and transpiration from the vegetation. We calculate MAAI for each NJF pixel and compare mean annual precipitation (annual totals for each year of the study period) and summer diurnal temperature ranges (i.e., for December, January, February) for each summer over the study period. We classify our MAAI in the same way as Middleton's [52] aridity ratio of precipitation to potential evaporation for the purposes of comparison (Table 1). 
Table 1. Aridity-humidity Classification of the value of MAAI, the ratio of actual to potential evaporation (after [52]).

\begin{tabular}{cc}
\hline Class & Range \\
\hline Hyperarid & 0 to 0.05 \\
Arid & 0.06 to 0.20 \\
Semi-arid & 0.21 to 0.50 \\
Dry-subhumid & 0.51 to 0.65 \\
Humid and wet & $>0.66$ \\
\hline
\end{tabular}

Detailed or gridded meteorological observations of surface energy fluxes do not currently exist across the forest. As such, the best available alternative are to surrogate bioclimatic indices with known biological significance [53] derived using the best available data, in this case- AWAP [39]. Using the AWAP climatologies [39] 19 bioclimatic indices (Table 2) were derived using the R-Project species distribution modeling package 'dismo' [54] and combined with MAAI to make a total of 20 indices. The bioclimatic indices summarise the total energy and water inputs across the NJF at seasonal and annual timescales. They characterise the climatic envelope and identify any thresholds contributing to the POM occurrences following the summer of 2010-2011.

Table 2. Nineteen bioclimatic indices calculated for the analysis (after [53]).

\begin{tabular}{|c|c|}
\hline Index & Description \\
\hline BIO01 & Annual Mean Temperature \\
\hline $\mathrm{BIO} 2$ & $\begin{array}{l}\text { Mean Diurnal Range (Mean of monthly (max temp - } \\
\text { min temp)) } ; \mathrm{T}_{\mathrm{mdr}}\end{array}$ \\
\hline $\mathrm{BIO} 03$ & Isothermality $\left(\mathrm{T}_{\mathrm{mdr}} / \mathrm{T}_{\mathrm{ara}}\right)(\times 100)$ \\
\hline $\mathrm{BIO} 04$ & Temperature Seasonality (standard deviation $* 100$ ) \\
\hline BIO05 & Max Temperature of Warmest Month; $\mathrm{T}_{\mathrm{wmo}}$ \\
\hline $\mathrm{BIO} 06$ & Min Temperature of Coldest Month; $\mathrm{T}_{\mathrm{cmo}}$ \\
\hline BIO07 & Temperature Annual Range $\left(\mathrm{T}_{\mathrm{wmo}}-\mathrm{T}_{\mathrm{cmo}}\right) ; \mathrm{T}_{\mathrm{ara}}$ \\
\hline $\mathrm{BIO} 08$ & Mean Temperature of Wettest Quarter \\
\hline BIO09 & Mean Temperature of Driest Quarter \\
\hline BIO10 & Mean Temperature of Warmest Quarter \\
\hline BIO11 & Mean Temperature of Coldest Quarter \\
\hline $\mathrm{BIO} 12$ & Annual Precipitation \\
\hline $\mathrm{BIO} 13$ & Precipitation of Wettest Month \\
\hline $\mathrm{BIO} 14$ & Precipitation of Driest Month \\
\hline BIO15 & Precipitation Seasonality (Coefficient of Variation) \\
\hline BIO16 & Precipitation of Wettest Quarter \\
\hline $\mathrm{BIO} 17$ & Precipitation of Driest Quarter \\
\hline $\mathrm{BIO} 18$ & Precipitation of Warmest Quarter \\
\hline BIO19 & Precipitation of Coldest Quarter \\
\hline
\end{tabular}

The aggregate of monthly inputs into the seasonal variables enable the detection of inter-annual shifts in seasonality; BIO15 relates to shifts in seasonal precipitation occurrence, known to be directly related to vegetation drought stress [55] and BIO14 focuses specifically to precipitation in the dry season, in the NJF this is in the summer months (December, January and February). 
The mean summer diurnal temperature range, and annual precipitation, used in the climate space analysis, provides insight into the range and magnitude of the energy inputs of temperature and specifically on precipitation preceding the mortality event. The approach assisted in identifying the key variables in the bioclimatic space, preceding and thus contributing to the mortality event. This deterministic methodology is consistent with others which use the response of plant functional traits to model their distribution [56,57] and persistence under variable climate scenarios [58,59].

\section{Results}

\subsection{Detection of POM and the Accuracy Assessment}

The spatial extent of the study area was $6074.5 \mathrm{ha}\left(60 \mathrm{~km}^{2}\right)$. The expert assessment of the $135 \mathrm{~km}^{2}$ grid resulted in greater accuracy in the detection of POM, $85 \%$ hit versus $74 \%$ missed, as compared to grid cells containing no death at all (Table 3). However, there were more than 2.5 times more cells containing POM than there were healthy ones. No POM were delineated inside the "validation" area (Figure 2(b)) and assessment of the presence and absence was conducted independently by forestry professionals (Batini personal communications. 2011).

Table 3. Confusion matrix of the object based classification of the presence and absence of healthy $(n=38)$ and patches of mortality $(n=97)$ across $135 \mathrm{~km}^{2}(\mathrm{n}=135)$ within in the NJF.

\begin{tabular}{ccc}
\hline & Healthy & POM \\
\hline Healthy & $74 \%(\mathrm{n}=28)$ & $26 \%(\mathrm{n}=10)$ \\
POM & $15 \%(\mathrm{n}=15)$ & $85 \%(\mathrm{n}=82)$ \\
\hline
\end{tabular}

Examples of the comparison of the POM identified in-situ and use for training the model (Figure 2(a).) reveal the complexity of the patch shapes and their stark visual differences between the surrounding, healthy vegetation. Figure 2 is a false-colour image in which red dominant colours indicate photosynthetically active cover (i.e., brighter red = more leaves), green-grey-black colours indicate non-photosynthetic cover and white colours are generally indicative of the high levels of reflection from bare soil and sands. Figure 3 shows the distribution of the POM across the study area including those areas excluded.

\subsection{Changes in Fractional Cover}

The MODFC data were used to investigate if an event of comparable extent had occurred prior to the summer of 2010-2011 and quantify the decadal natural variability in fractional cover across the study area. At $0.5 \mathrm{~km}$ resolution the MODFC data potentially contains information on changes in fractional cover for none, one or many POM (i.e., those detected from $10 \mathrm{~m}$ resolution SPOT-5 data). When MODFC is aggregated to $5 \mathrm{~km}$ the climate data will contain information relevant to many MODFC pixels. Addressing this spatial disparity the MODFC data were aggregated to $5 \mathrm{~km}$ and both the study area and POM location trends are extracted for comparison. This provided spatial parity between the impact of the POM in MODFC and AWAP data at $5 \mathrm{~km}$ yet did not yield any significant differences in the occurrence of the MSD exceedance events (data not shown). 
Figure 3. SPOT-5 Imagery overlaid with the mining, water and cloud masks used across the study area in modeling POM and the validation grid used.

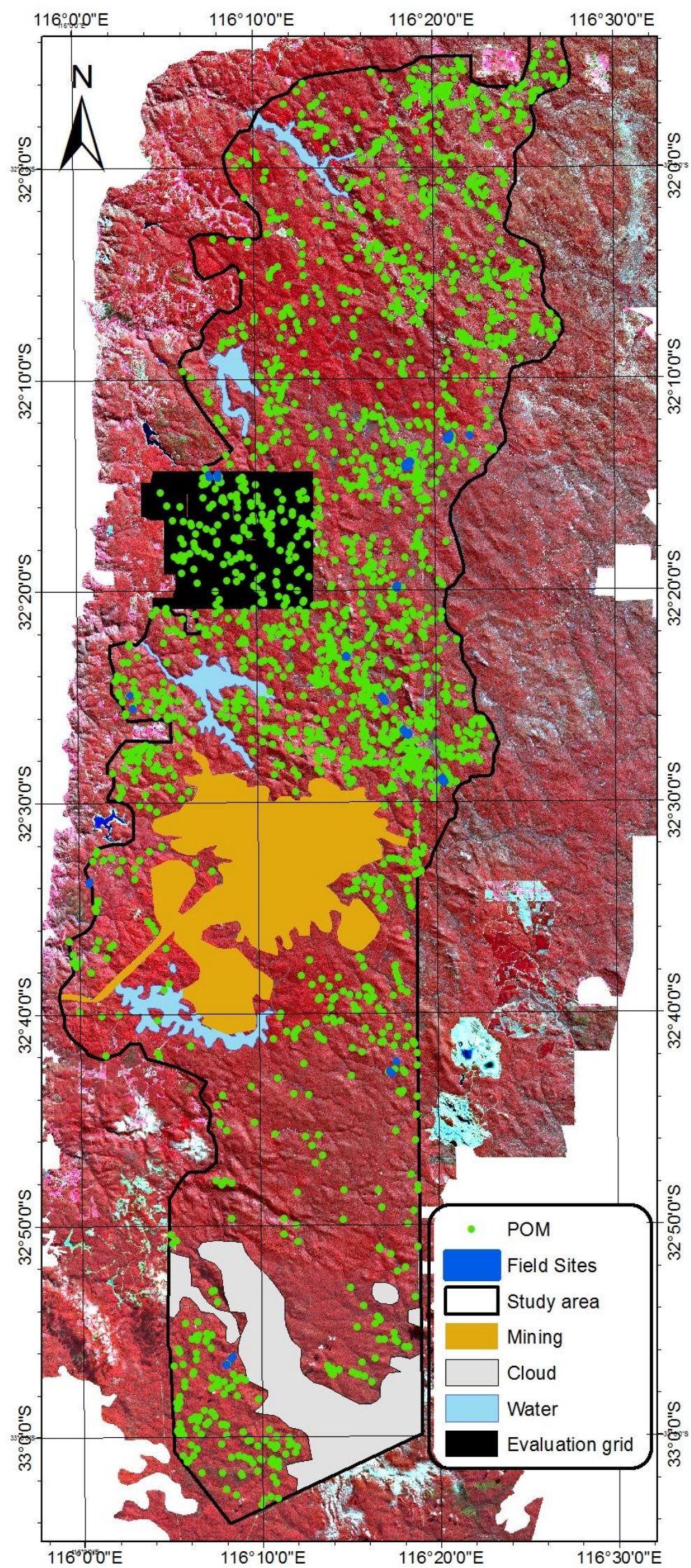


Considering all pixels across the study area, the MODFC time series (refer Figure 4) shows a simultaneous decrease in $\mathrm{f}_{\mathrm{pv}}$ (Figure 4(a).) and increase in $\mathrm{f}_{\text {npv }}$ (Figure 4(b).) occurred following the summer of 2010-2011. Additionally, around 2001, there was a significant drop in $\mathrm{f}_{\mathrm{pv}}$, which did not coincide with an increase in $\mathrm{f}_{\text {npv. }}$. Comparing only pixels containing a modeled estimate POM, the average of all of these pixels (Figure 5) shows an equally clear and significant decline in $f_{p v}$ corresponding with an increase in $\mathrm{f}_{\text {npv }}$ and importantly there was no significant change in $\mathrm{f}_{\mathrm{bs}}$ over the summer 2010-2011 period. In contrast to the impacts across the study area (Figure 5) there was no significant decrease in $\mathrm{f}_{\mathrm{pv}}$ during the summer of 2001-2002.

Figure 4. Spatially aggregated $0.5 \mathrm{~km}$ study area average Seasonal Trend Decomposition using Loess (STL) trend plots showing the 2000-2012 period with the summer of 2010-2011 marked for each component of MODFC Guerschman [33]. Subplot (a) is the fraction $(\%)$ of photosynthetic cover $\left(\mathrm{f}_{\mathrm{pv}}\right)$; (b) the fraction $(\%)$ of non-photosynthetic cover $\left(f_{\text {npv }}\right)$ and c. the fraction $(\%)$ of bare soil $\left(f_{b s}\right)$.
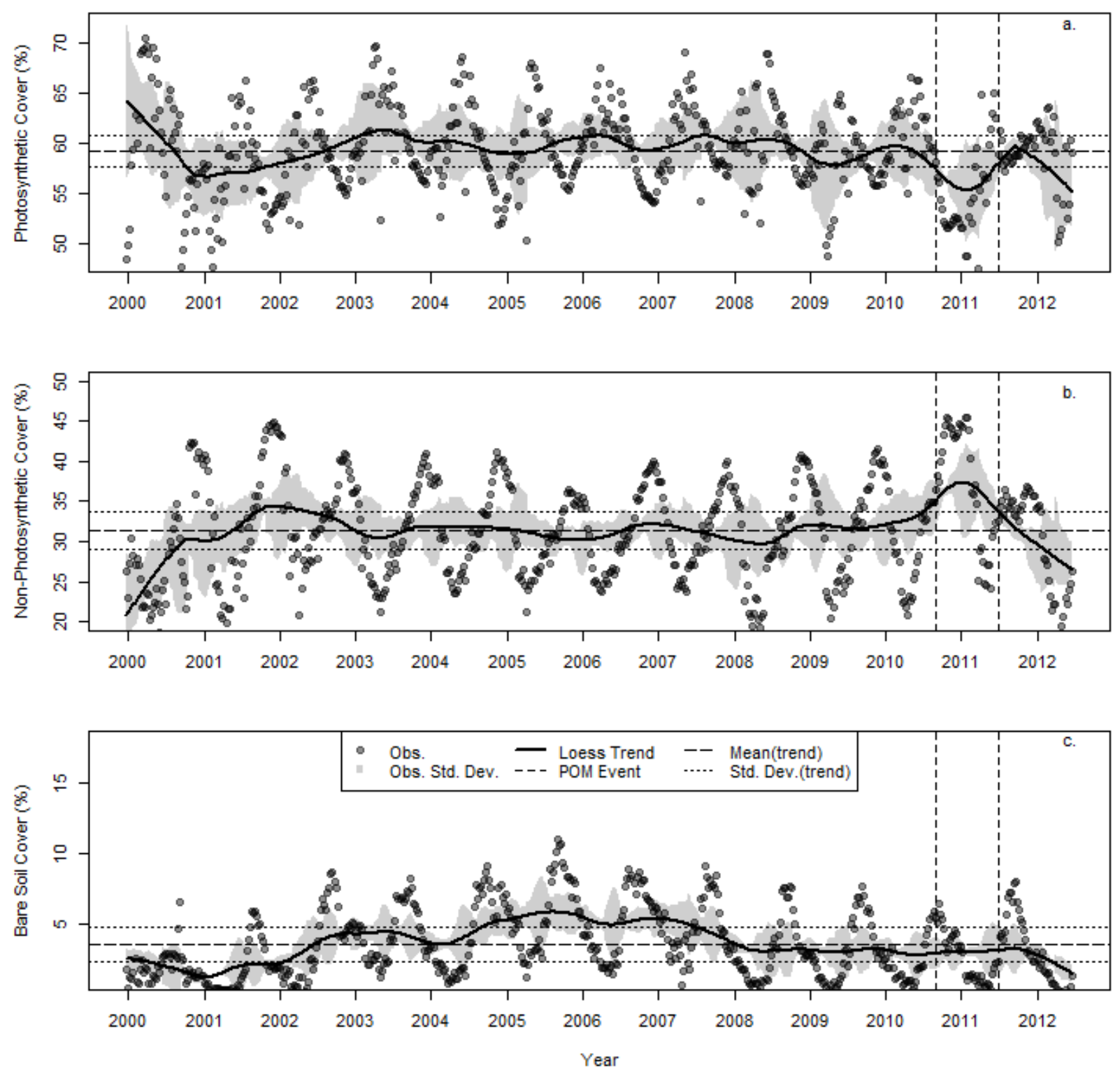
Figure 5. $0.5 \mathrm{~km}$ POM average STL trend plots showing the 2000-2012 period with the summer of 2010-2011 marked for each component of MODFC after Guerschman [33]. Subplot (a) is the fraction $(\%)$ of photosynthetic cover $\left(f_{\mathrm{pv}}\right)$; $(\mathbf{b})$ the fraction $(\%)$ of non-photosynthetic cover $\left(\mathrm{f}_{\mathrm{npv}}\right)$ and $(\mathbf{c})$ the fraction $(\%)$ of bare soil $\left(\mathrm{f}_{\mathrm{bs}}\right)$.
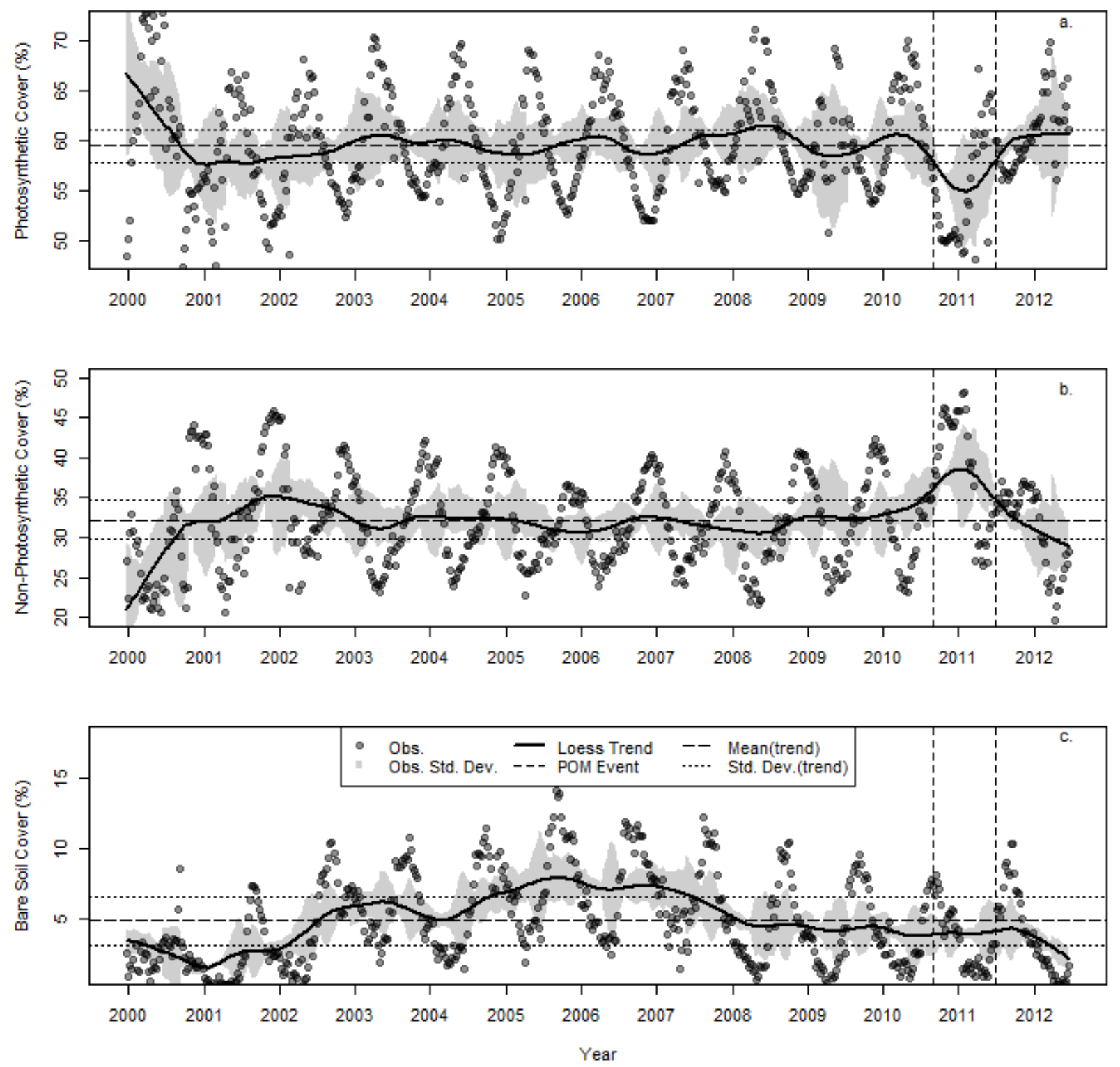

\subsection{The Changing Climatic Space}

Spatial analysis of the temporal climate data revealed the NJF has been experiencing a sustained net average reduction in precipitation over the last three decades. Annual precipitation in 2009 was $69 \%$ less $(301 \mathrm{~mm} \pm 38 \mathrm{~mm}$ ) than the mean of 1981-2010 (907 $\mathrm{mm} \pm 69 \mathrm{~mm})$. In 2010, was $47 \%$ less (477 $\mathrm{mm} \pm 38 \mathrm{~mm}$ ) over the same period (refer Figure 6). Over this two year period, the study area received $1038 \mathrm{~mm}$ less precipitation than the long term mean which resulted in the ecosystem shifting to a more arid regime. Figure 6 shows pockets of sub-humid climate retracted to a more semi-arid climate. 
Figure 6. Spatially aggregated comparison of the NJF's Mean Annual Aridity Index versus Mean Annual Precipitation (mm/year). Averages over the period 1981-2009 are shown in grey and the 2010-2011 in black.

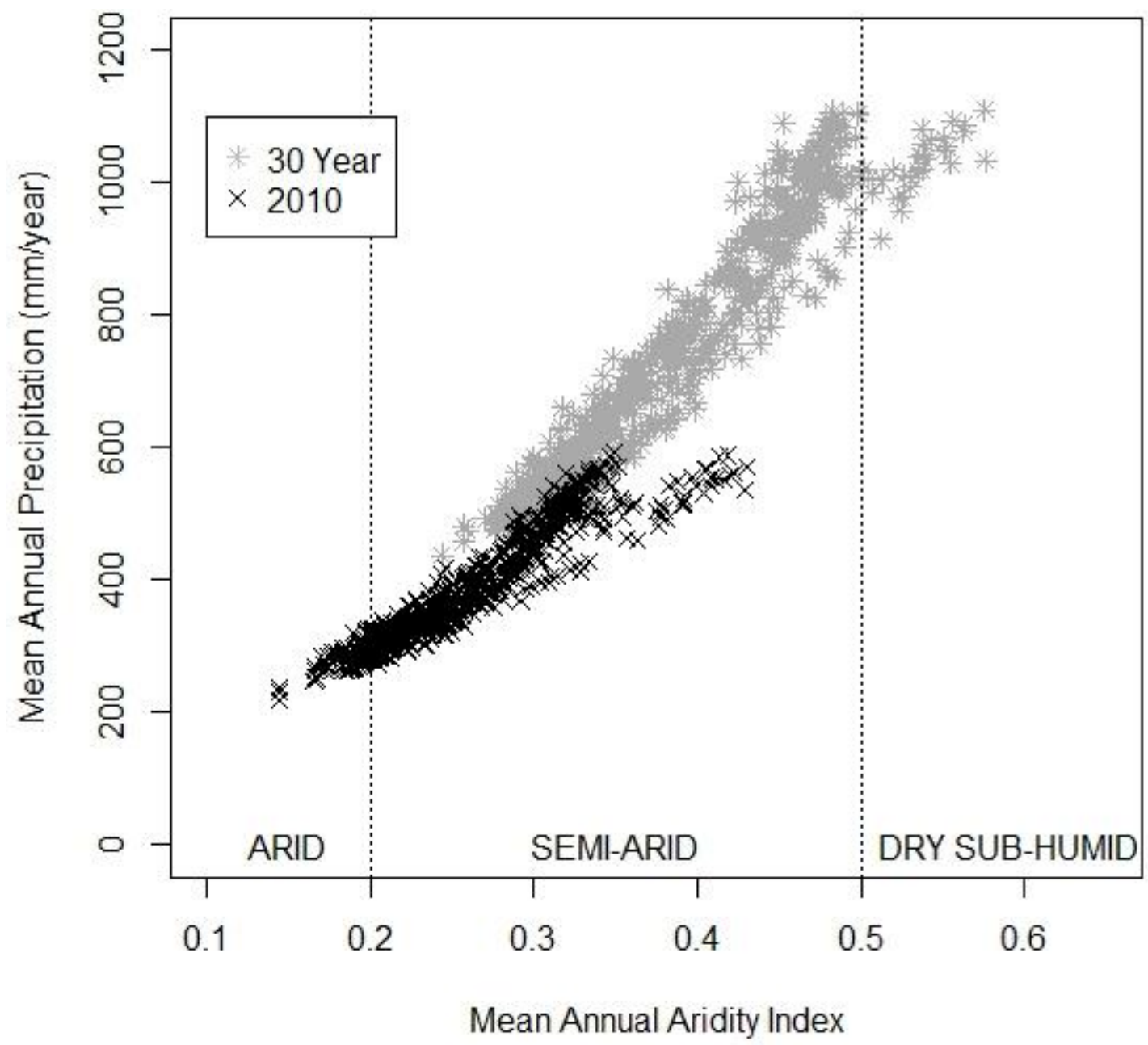

The study area has also been getting hotter over the study period. Summer $2010-2011$ was $1.1{ }^{\circ} \mathrm{C}$ $\left(17.7^{\circ} \mathrm{C} \pm 5.3^{\circ} \mathrm{C}\right)$ warmer than the average summer temperatures $\left(16.6{ }^{\circ} \mathrm{C} \pm 4.6{ }^{\circ} \mathrm{C}\right)$ of the last three decades (1981-2011). This rate of warming has been increasing over the last decade. Whilst the annual mean minimum temperature across the study area was $0.2{ }^{\circ} \mathrm{C} \pm 4.7{ }^{\circ} \mathrm{C}$ cooler $\left(10.1{ }^{\circ} \mathrm{C} \pm 4.7{ }^{\circ} \mathrm{C}\right)$ than the last three decades $\left(10.3{ }^{\circ} \mathrm{C} \pm 3.6{ }^{\circ} \mathrm{C}\right)$, the summer mean and maximum temperatures were higher. The mean 2010-2011 summer maximum temperature was $1.4{ }^{\circ} \mathrm{C}\left(31.6{ }^{\circ} \mathrm{C} \pm 2.0{ }^{\circ} \mathrm{C}\right)$ higher than the previous 30 years $\left(30.2{ }^{\circ} \mathrm{C} \pm 2.0{ }^{\circ} \mathrm{C}\right.$ ). The 2010 annual mean diurnal range (BIO02) (Figure 7) $\left(\mathrm{T}_{\max }-\mathrm{T}_{\min }\right)$ was $1.6{ }^{\circ} \mathrm{C}$ higher $\left(14.7^{\circ} \mathrm{C} \pm 0.5{ }^{\circ} \mathrm{C}\right)$ than the mean of the study period $\left(13.1{ }^{\circ} \mathrm{C} \pm 0.5\right.$ $\left.{ }^{\circ} \mathrm{C}\right)$. As with precipitation, this illustrates a shift from a predominately semi-arid envelope towards an increasing arid one- completely departing its sub-humid zones.

\subsection{Bioclimatic Indices and the Aggregated Extremes}

The spatially aggregated indices (Figure 8) show the biologically significant changes in climate across the NJF between 1981-2010. There is a gradually increasing trend (1981-2010) in mean annual temperature (BIO01 refer Figure 8) driven by both an increase in the frequency of mean temperature 
years (white) over the last decade and a reduction in the frequency of cooler years (blue) between the hotter, more extreme years (red). The temperature indices, BIO05 (maximum temperature of the warmest month) and BIO06 (minimum temperature of the coldest month), show that warmest and coldest months have been less warm during 2000-2008 compared to 1981-1999. BIO05 shows 2009 and 2010 are the warmest of the last decade. BIO06 shows three of the coldest months between 2006-2010 were colder. Simply put, the seasonal temperature extremes are expanding, the coolest months are getting colder and the warmest- hotter. In 2010, the annual range of temperature (BIO07) was the highest of the entire study period. Winter (i.e., June, July and August) in SWWA is usually the wettest part of the year and the mean temperature of the wettest quarter (BIO08) has been declining in intensity since 2005. Summer (i.e., December, January and February) usually falls in the driest and warmest quarter and the mean temperature of the driest quarter (BIO09) has been on a warming trend since 2005 as has the mean of the warmest quarter (BIO10). Although the coldest month (BIO06) is getting colder, the mean of the coldest quarter (BIO011) has been increasing.

Figure 7. Spatially aggregated comparison of the NJF's Mean Annual Aridity Index versus Summer (December, January and February) Average Diurnal Temperature Range (deg C). Averages over the period 1981-2009 are shown in grey and the 2010-2011 in black.

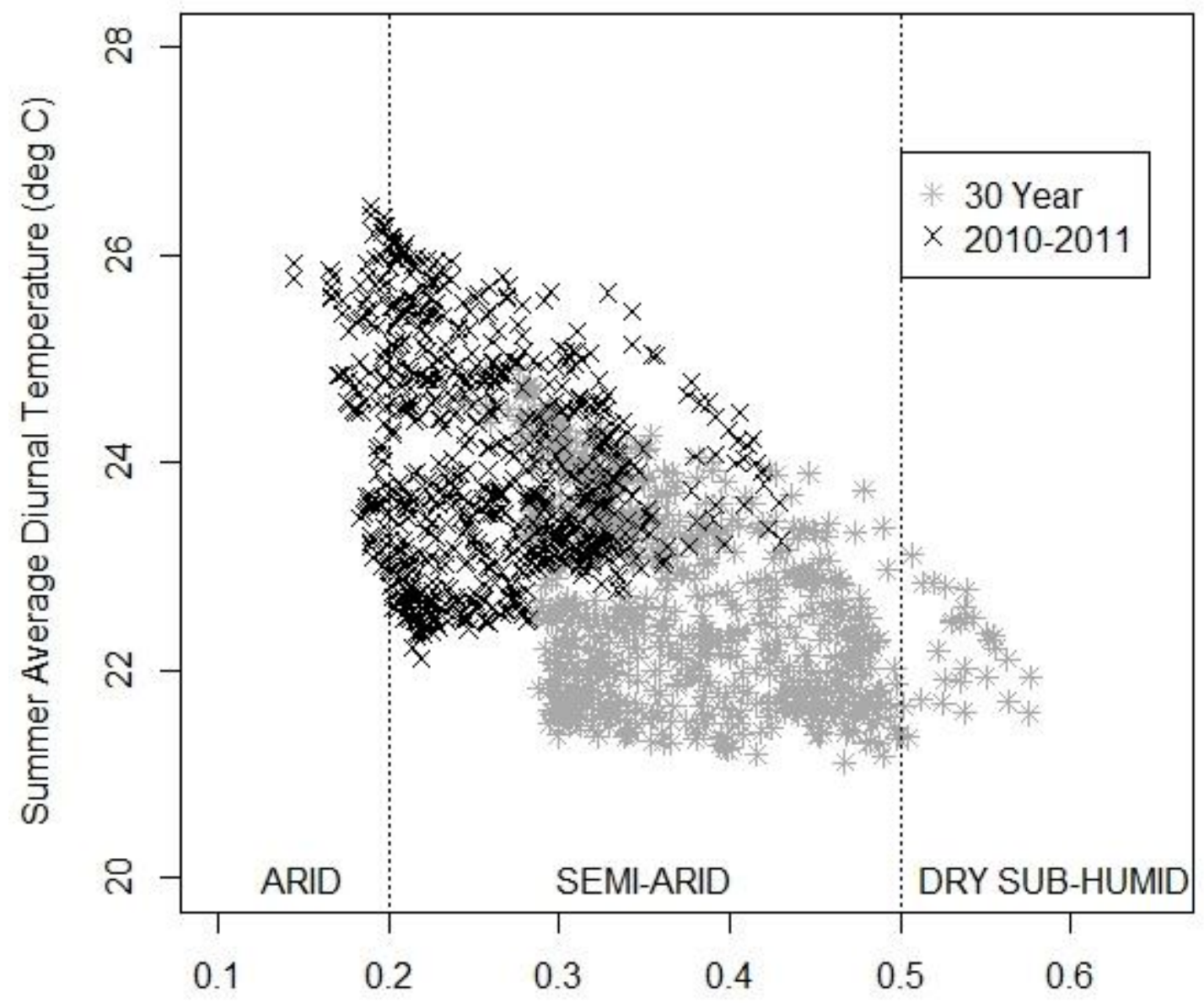

Mean Annual Aridity Index 
Figure 8. Relatively scaled (by index) hepta-class heatmap of NJF spatially aggregated bioclimatic variables [53] for the period 1981-2010. Derived from the AWAP [39] using Hijmans et al. [54]. Red colours represent quantities greater than the mean (white) and blue less than, intensity represents magnitude.

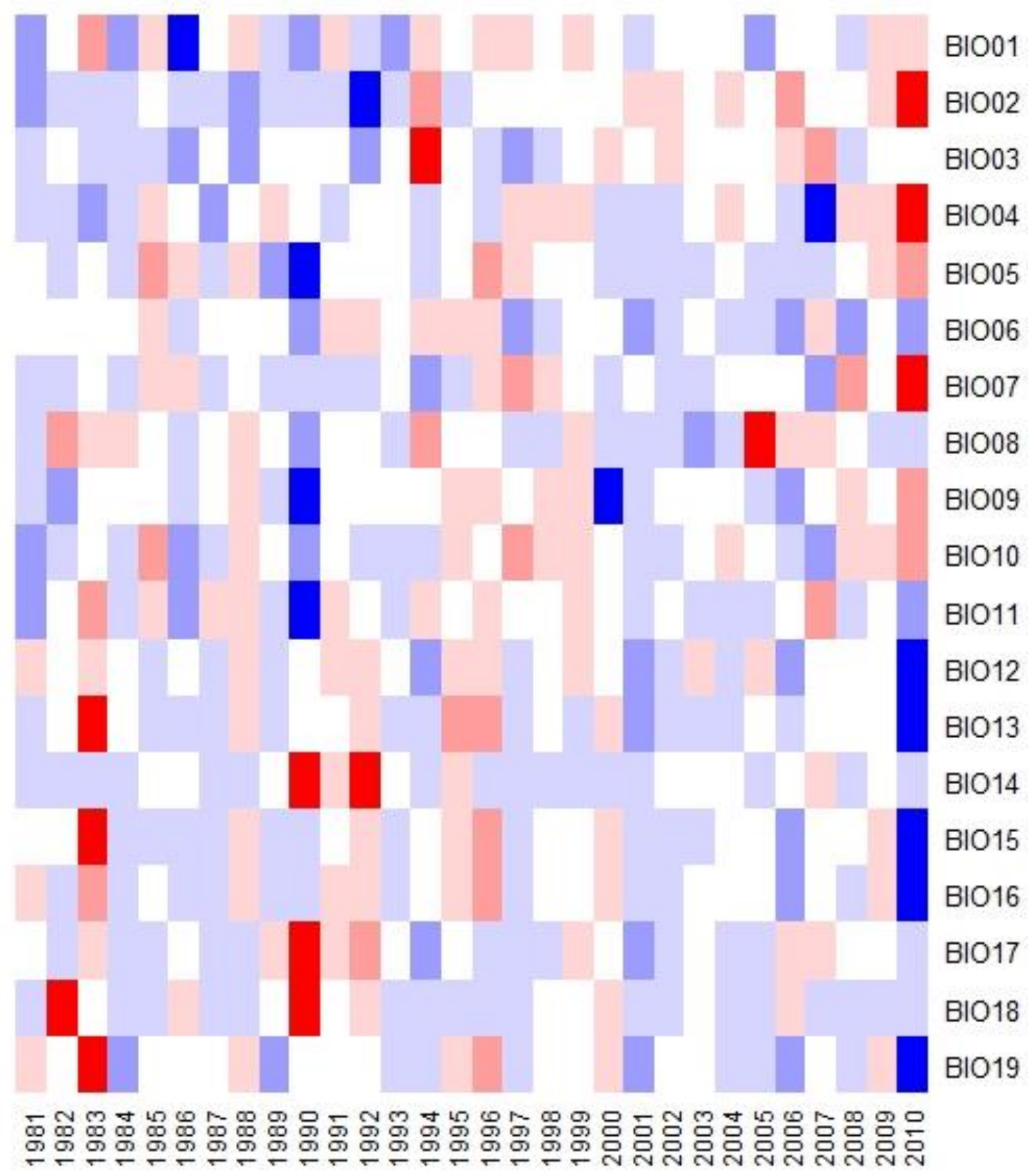

The mean diurnal range (BIO02), the mean of the difference of the monthly maximum and minimum temperatures over a year, shows a consistent annual increase (Figure 9) in cold and warm extremes developing over the last decade. BIO02 has increased at a consistent rate throughout the study period. BIO02 exceeded the MSD, for the first time in the study period, around winter 2004 and has continued to increase since. 
Figure 9. BIO02 is the 'Mean Diurnal Range', the mean of the difference of the monthly maximum and minimum temperature [53], for the period 1981-2010. Derived from the AWAP [39] using Hijmans et al. [54].

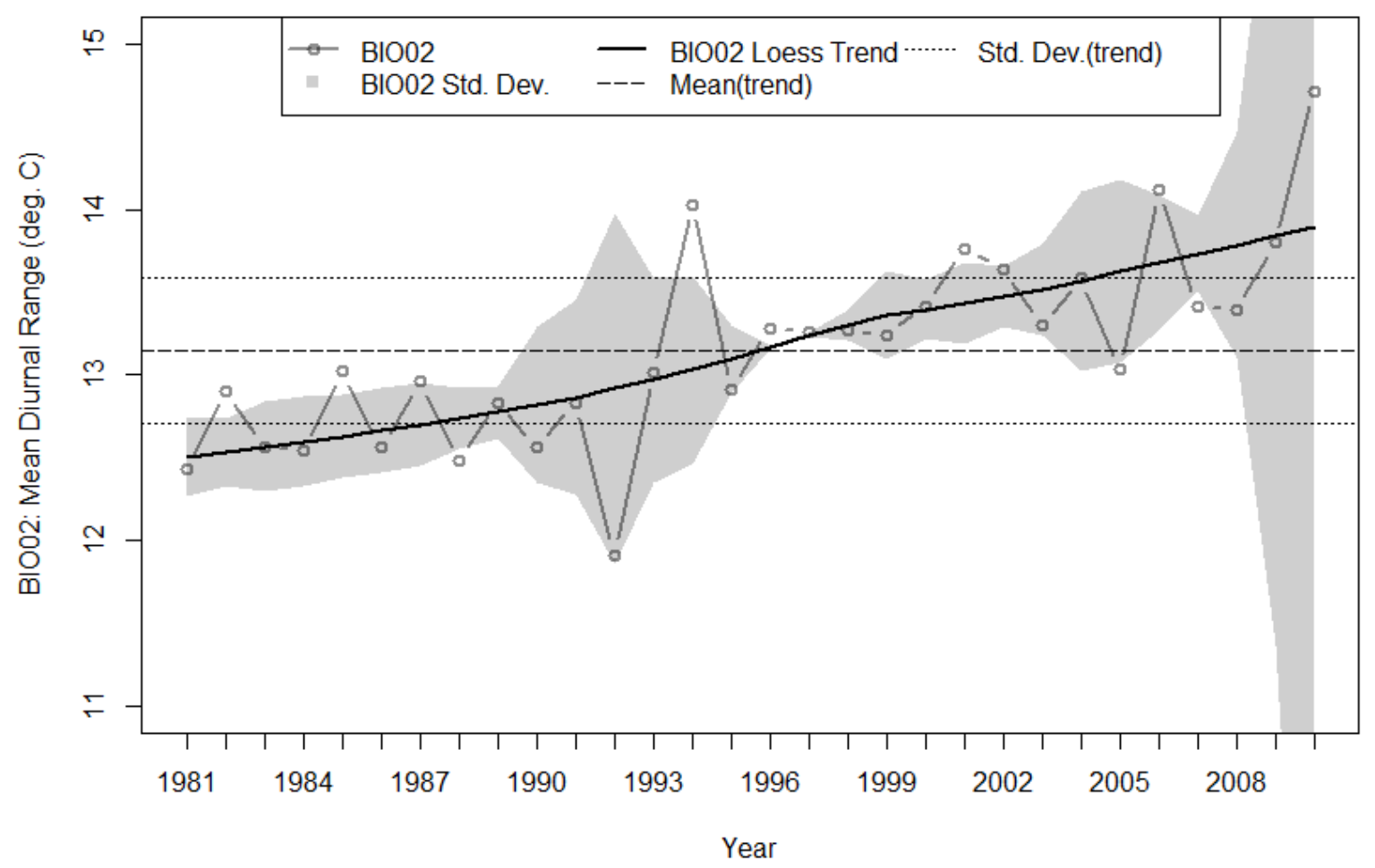

Figure 10. Spatial aggregated monthly time series of mean daily rainfall $(\mathrm{mm})$ across the study area showing the loess trend, mean and standard deviations and the original monthly data, extracted from AWAP [39] for the period 1981-2010.

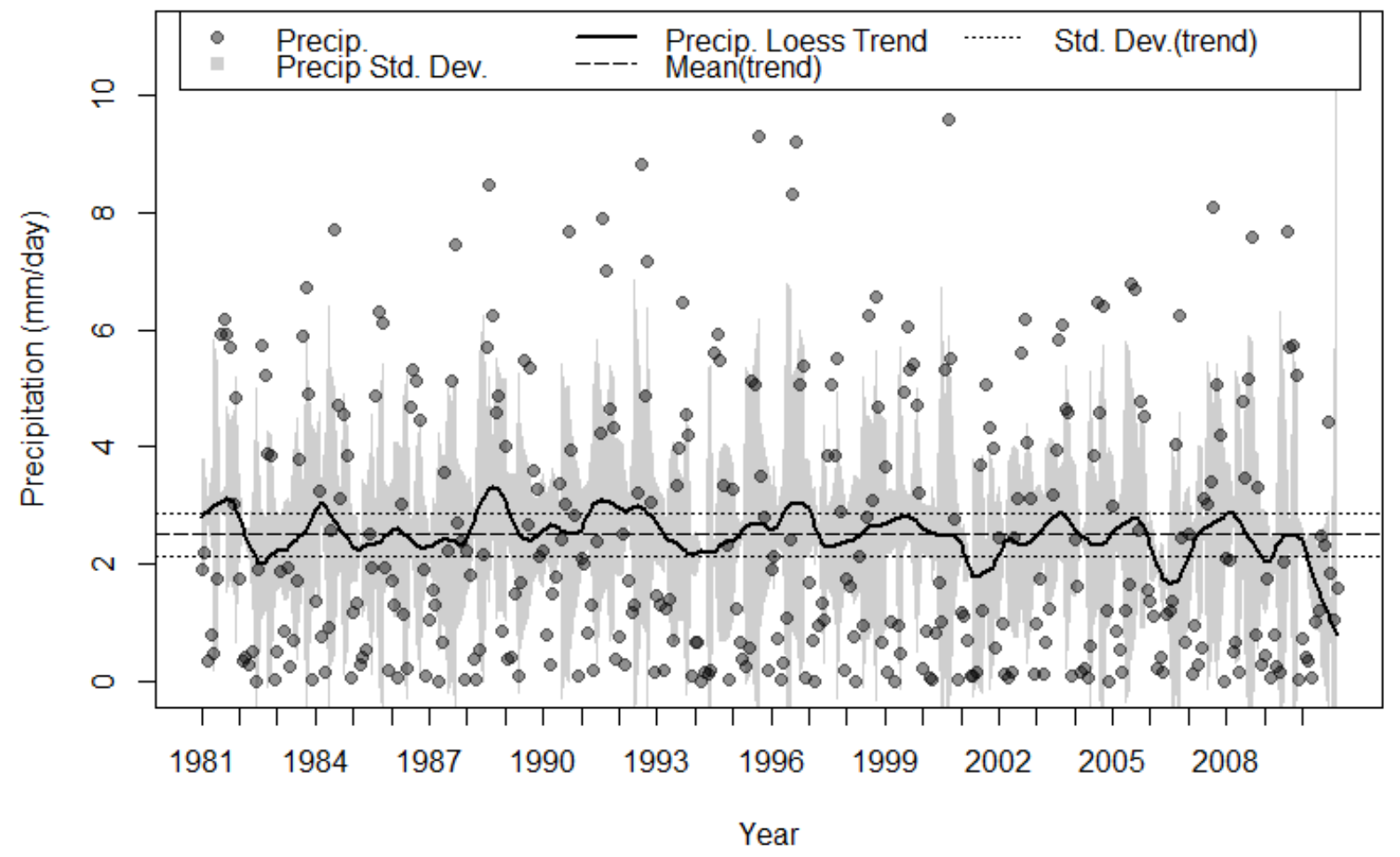


The precipitation indices, BIO12-BIO19 (Figure 8) show the observed reduction in rainfall progressively increasing over the last decade which decreases to an extreme minimum over the last three years with the most extreme deficit occurring in 2010. The AWAP precipitation data (Figure 10) shows the significance of these drier years over recent decades and significant declines (i.e., less than the MSD) occurring in 2001, 2006 and 2009. Prior to 2000 there were significantly wet years (i.e., greater than the MSD) in 1981, 1984, 1988, 1992 and 1997 and none between 1998 and 2010. The annual precipitation (BIO12) clearly shows both a reduction in the magnitude of the wet years (19811990) and an increase in the magnitude of the dry years (1991-2010). The frequency of wet years shifts (BIO14 and BIO15) away from a cycle of a one-in-five marked wet years (1981-2000) to an eight year run of below-average precipitation (2001-2008) preceding the extremely dry period 2008-2010. This tendency is also captured in the seasonal precipitation indicators (BIO16-BIO19); whilst less strong, there are no extremely wet events since 1990.

\section{Discussion}

Over the last decade the study area has become drier, and the mean annual diurnal temperature range more extreme, increasing the risk of damage and mortality from a change in the frequency and intensity of heat waves and the potential for frost. As precipitation decreased the forest was exposed to greater mean annual diurnal temperature range which in turn contributed to an increase in evapotranspiration and gradually resulted in a bioclimatic shift towards aridity. These results suggest the bioclimatic factors preconditioning the POM across the study area were:

1. A succession of warm summers with summer maximum temperatures in 2010-2011 $1.4{ }^{\circ} \mathrm{C}$ hotter than the 30 year average.

2. A sustained multi-decadal reduction in wet years over the last 30, with 1982 being the wettest.

3. A succession of extremely dry years, 2009 was $69 \%$ less than the 30 year average and 2010 was $47 \%$ less over the same period.

4. A sustained increase in BIO02 over the last decade, peaking in 2010 at $1.6{ }^{\circ} \mathrm{C}$ above the 30 year average.

Whilst it is well documented that climatic warming is expected for the southwest of Western Australia, we found that the increased diurnal temperature range (BIO02) was a stronger indicator than an independent change in the maximum temperature- which was expected [55]. Minimum temperatures also declined as the temperatures become more extreme (hot and cold) the mean annual diurnal temperature range is increasing, reaching a study period maximum of $14.7^{\circ} \mathrm{C} \pm 0.5^{\circ} \mathrm{C}$ in 2010 . This greater range increases the chance of frost in winter and heat waves in summer. In combination, the results suggests that in the presence of drought, exposure to both more intense cold and heat compounded vegetation water stress sufficiently to exhaust available energy reserves required for rooting and transpiration defense strategies- an effect found in plantation forests where soil depth and water storage capacity were found to be low [16].

This 2010-2011 event is also similar to the documented genesis of other forest mortality episodes [1] for which it is argued that they will ultimately accelerate species turnover and drive landscape evolution as climates shift under global climate change [60,61]. These results also concur 
with the pioneering bioclimatic analysis of Gentilli [20] who predicted a similar precipitation threshold $(+/-300 \mathrm{~mm})$ as that which sustains the forest in its present geographic location. The spatial analysis shows a reduction of $1038 \mathrm{~mm}$ accumulated precipitation $(2009+2010)$, over $700 \mathrm{~mm}$ in excess of the Gentilli [20] threshold. When compared to the 1981-2011 mean, this equates to 69\% less in 2009 and $47 \%$ less in 2010. As the climate of SWWA continues to become dryer and warmer we need to improve our understanding of the relationships between key climatic indicators and the spatiotemporal responses of our native forests at the landscape scale.

More recently, numerous studies have identified the bioclimatic envelopes that drive trait based species distribution across landscapes. The underlying objective of these studies is to parameterise models that attempt to predict future climate change vulnerability and the adaptive capacity of specific forest types (e.g., [8,37]). Many of these studies claim there is no clear link between strong-drought induced water stress and plant physiological responses [62-64] on the basis that stomatal control limits carbon assimilation during drought $[65,66]$. The precipitation data shown here suggests water limitation (i.e., drought and water stress) has been the primary driver of this mortality event.

Recent studies of Mediterranean climates indicate that severe droughts can result in non-stomatal limitation of photosynthesis relative to leaf water stress [67] when driven by low water availability and high evaporative demand over time [68,69]. Such responses confound the assimilatory capacity of vegetation and in severe drought conditions, can exceed physiological water-carbon deficiency thresholds that could in turn trigger reduced recovery hysteresis, cascading effects and mortality [24,70-72]. Further confounding this debate is evidence that slightly warmer temperatures within a tree's optimum range could enhance forest growth under enhanced $\mathrm{CO}_{2}$ [73].

Satellite imagery has become a well-accepted source of information, providing useful information on the spatio-temporal variation of vegetated landscapes. In this study we used 3 different remotely sensed data; (1) DMSI airborne imagery (0.5 m), (2) SPOT-5 high-resolution (10 m) and (3) MODIS moderate resolution $(0.5 \mathrm{~km})$ satellite imagery that were further aggregated to $5 \mathrm{~km}$. We combined them to first detect and map a decline event at a single point in time, highlighting the significant spatial extent of the event. Then we go back in time to understand how the past impacted on the changes in photosynthetic cover (i.e., forest canopy) we observed and modeled following the summer of 2010-2011. We found both satellite sensors (SPOT-5 and MODIS) detected changes in photosynthetic and non-photosynthetic cover following the summer of 2010-2011. The MODFC data provided a long-term (2000-2012) baseline for fractional cover suggesting that in the years prior to the 2010-2011 event the POM modeled sites were persisting within their environmental niche- in a "healthy" state with no evidence of widespread stress. In addition to the independent validation, the MODFC analysis provides greater confidence in this multiple sensor methodology. The similar results following spatial down-aggregation of the MODFC data, i.e., to the same resolution as the climatologies, adds yet further confidence to the usefulness of MODFC for mapping such events at lower resolutions when no better data are available. Additionally, this approach demonstrates the potential use of programmable satellites such as SPOT-5 to acquire these data on demand and for broad-scale, near-real time post-mortem POM detection.

The threat of fire in the NJF remains significant as long as the residues of each POM remain scattered across the forest. Should the POM combust, it could potentially create a wildfire in the same way that the 1998 Yellowstone fires evolved from distributed patches into one large conflagration 
which persisted for months [74] and such an event could have a significant impact on the biodiversity of the flora and fauna of the forests structure and threaten the welfare of the local population.

\section{Conclusion}

Expansion of the thermal extremes of minimum and maximum temperature and prolonged drought were major drivers of forest mortality in the NJF following the summer of 2010-2011. This forest scale mortality event was successfully captured using SPOT-5 imagery using a three-rule feature extraction algorithm that produced a map of their distribution across the landscape. Used in this way, the combination of remote sensing and gridded climatologies provides a means of monitoring, mapping and analyzing the drivers of bioclimatic induced change of forested ecosystems for known events and a basis for a new generation models on similar spatial and temporal scales. As such, this approach makes a significant contribution towards a robust methodology for monitoring the impact of climate induced drought and the underlying ecological consequences of extreme climate variability on forest dynamics.

\section{Acknowledgments}

We thank Planet Action and Astrium Services for supplying the SPOT-5 Imagery and Excelis Visual Information services for providing ENVI, ENVI EX and FLAASH for processing the imagery. Thanks to the Water Corporation and SpecTerra Services Ltd. for their substantial support in the provision of the orthorectified digital multispectral imagery utilised for this study. Thanks to Matt Paget and Peter Scarth for their advice on usage of the TERN AusCover data. Special thanks to Peter Briggs and Michael Raupach from CSIRO Marine and Atmospheric Research for making the AWAP datasets publicly available and several discussions on recent version changes to these data. Special thanks to Nicholas Coops and Christine Stone and the anonymous reviewers for their feedback at various stages. The work of Bradley Evans is supported by a Murdoch University PhD scholarship and a Centre of Excellence for Climate Change Woodland and Forest Health scholarship.

\section{Conflict of Interest}

The authors declare no conflict of interest.

\section{References}

1. Allen, C.D.; Macalady, A.K.; Chenchouni, H.; Bachelet, D.; McDowell, N.; Vennetier, M.; Kitzberger, T.; Rigling, A.; Breshears, D.D.; Hogg, E.H. (Ted); et al. A global overview of drought and heat-induced tree mortality reveals emerging climate change risks for forests. For. Ecol. Manag. 2010, 259, 660-684.

2. Hughes, L. Climate change and Australia: Key vulnerable regions. Reg. Environ. Chang. 2010, $11,189-195$. 
3. Prober, S.M.; Thiele, K.R.; Rundel, P.W.; Yates, C.J.; Berry, S.L.; Byrne, M.; Christidis, L.; Gosper, C.R.; Grierson, P.F.; Lemson, K.; et al. Facilitating adaptation of biodiversity to climate change: A conceptual framework applied to the world's largest Mediterranean-climate woodland. Clim. Chang. 2011, 110, 227-248.

4. McDowell, N.; Pockman, W.T.; Allen, C.D.; Breshears, D.D.; Cobb, N.; Kolb, T.; Plaut, J.; Sperry, J.; West, A.; Williams, D.G.; et al. Mechanisms of plant survival and mortality during drought: Why do some plants survive while others succumb to drought? N. Phytol. 2008, 178, 719-739.

5. Abbott, I.; Le Maitre, D. Monitoring the impact of climate change on biodiversity: The challenge of megadiverse Mediterranean climate ecosystems. Austral. Ecol. 2009, 35, 406-422.

6. Llorens, L.; Penuelas, J.; Estiarte, M. Ecophysiological responses of two Mediterranean shrubs, Erica multiflora and Globularia alypum, to experimentally drier and warmer conditions. Physiol. Plant. 2003, 119, 231-243.

7. Dunlop, M.; Brown, P.R. Implications of Climate Change for Australia's National Reserve System: A Preliminary Assessment; Report to the Department of Climate Change: Canberra, Australia, 2008.

8. West, A.G.; Dawson, T.E.; February, E.C.; Midgley, G.F.; Bond, W.J.; Aston, T.L. Diverse functional responses to drought in a Mediterranean-type shrubland in South Africa. N. Phytol. 2012, 195, 396-407.

9. Lane, P.N.J.; Feikema, P.M.; Sherwin, C.B.; Peel, M.C.; Freebairn, A.C. Modelling the long term water yield impact of wildfire and other forest disturbance in Eucalypt forests. Environ. Mod. Softw. 2010, 25, 467-478.

10. Kinal, J.; Stoneman, G.L. Hydrological impact of two intensities of timber harvest and associated silviculture in the Jarrah forest in south-western Australia. J. Hydrol. 2011, 399, 108-120.

11. Klausmeyer, K.R.; Shaw, M.R. Climate change, habitat loss, protected areas and the climate adaptation potential of species in mediterranean ecosystems worldwide. PLoS One 2009, 4, e6392.

12. Cai, Y.F.; Barber, P.; Dell, B.; O’Brien, P.; Williams, N.; Bowen, B.; Hardy, G. Soil bacterial functional diversity is associated with the decline of Eucalyptus gomphocephala. For. Ecol. Manag. 2010, 260, 1047-1057.

13. Evans, B.; Lyons, T.J.; Barber, P.A.; Stone, C.; Hardy, G. Dieback Classification Modelling using High Resolution Digital Multi Spectral Imagery and in situ Assessments of Crown Condition. Remote Sens. Lett. 2012, 3, 541-550.

14. Evans, B.; Lyons, T.J.; Barber, P.A.; Stone, C.; Hardy, G. Enhancing a eucalypt crown condition indicator driven by high spatial and spectral resolution remote sensing imagery. J. Appl. Remote Sens. 2012, 6, 1-15.

15. Mitchell, P.J.; Benyon, R.G.; Lane, P.N.J. Responses of evapotranspiration at different topographic positions and catchment water balance following a pronounced drought in a mixed species Eucalypt forest, Australia. J. Hydrol. 2012, 440-441, 62-74.

16. Harper, R.J.; Smettem, K.R.J.; Carter, J.O.; McGrath, J.F. Drought deaths in Eucalyptus globulus (Labill.) plantations in relation to soils, geomorphology and climate. Plant Soil 2009, 324, 199-207. 
17. Petrone, K.C.; Hughes, J.D.; Van Niel, T.G.; Silberstein, R.P. Streamflow decline in southwestern Australia, 1950-2008. Geophys. Res. Lett. 2010, 37, 1-7.

18. Bates, B.C.; Hope, P.; Ryan, B.; Smith, I.; Charles, S. Key findings from the Indian Ocean Climate Initiative and their impact on policy development in Australia. Clim. Chang. 2008, 89, 339-354.

19. Ruprecht, J.K.; Stoneman, G.L. Water yield issues in the Jarrah forest of south-western Australia. J. Hydrol. 1993, 150, 369-391.

20. Gentilli, J. Bioclimatic Controls in Western Australia EVAPO-TRANSPIRATION. West. Aust. Nat., Perth 1948, 1, 104-107.

21. Tobin, S. Seasonal climate summary southern hemisphere (summer 2009-2010): An El Niño summer? wetter than average for east, north and central areas, dry in Western Australia and Tasmania. Aust. Meteorol. Oceanogr. J. 2010, 60, 289-299.

22. Campbell, B. Seasonal climate summary southern hemisphere (autumn 2010): Rapid decay of El Niño, wetter than average in central, northern and eastern Australia and warmer than usual in the west and south. Aust. Meteorol. Oceanogr. J. 2011, 61, 65-76.

23. Imielska, A. Seasonal climate summary southern wettest Australian summer on record and one of the strongest La Niña events on record. Aust. Meteorol. Oceanogr. J. 2012, 61, 241-251.

24. Gutschick, V.P.; BassiriRad, H. Extreme events as shaping physiology, ecology, and evolution of plants: Toward a unified definition and evaluation of their consequences. N. Phytol. 2003, 160, 21-42.

25. Misson, L.; Degueldre, D.; Collin, C.; Rodriguez, R.; Rocheteau, A.; Ourcival, J.-M.; Rambal, S. Phenological responses to extreme droughts in a Mediterranean forest. Glob. Chang. Biol. 2011, 17, 1036-1048.

26. Barry, K.M.; Stone, C.; Mohammed, C.L. Crown-scale evaluation of spectral indices for defoliated and discoloured eucalypts. Int. J. Remote Sens. 2008, 29, 47-69.

27. Coops, N.; Stone, C.; Culvenor, D.S.; Chisholm, L. Assessment of Crown Condition in Eucalypt Vegetation. J. Environ. Qual. 2004, 33, 956-964.

28. Coops, N.; Dury, S.; Smith, M.-L.; Martin, M.; Ollinger, S. Comparison of green leaf eucalypt spectra using spectral decomposition. Aust. J. Bot. 2002, 50, 567.

29. Datt, B. Remote Sensing of Chlorophyll a, Chlorophyll b, Chlorophyll a+b, and Total Carotenoid Content in Eucalyptus Leaves. Remote Sens. Environ. 1998, 66, 111-121.

30. Haywood, A.; Stone, C. Mapping eucalypt forest susceptible to dieback associated with bell miners (Manorina. melanophys) using laser scanning, SPOT 5 and ancillary topographical data. Ecol. Mod. 2011, 222, 1174-1184.

31. Pietrzykowski, E.; Stone, C.; Pinkard, E.; Mohammed, C. Effects of Mycosphaerella. leaf disease on the spectral reflectance properties of juvenile Eucalyptus globulus foliage. For. Pathol. 2006, 36, 334-348.

32. Stone, C.; Chisholm, L.; Coops, N. Spectral reflectance characteristics of Eucalypt foliage damaged by insects. Aust. J. Bot. 2001, 49, 687-698.

33. Guerschman, J.P.; Hill, M.J.; Renzullo, L.J.; Barrett, D.J.; Marks, A.S.; Botha, E.J. Estimating fractional cover of photosynthetic vegetation, non-photosynthetic vegetation and bare 
soil in the Australian tropical savanna region upscaling the EO-1 Hyperion and MODIS sensors. Remote Sens. Environ. 2009, 113, 928-945.

34. Verbesselt, J.; Hyndman, R.; Newnham, G.; Culvenor, D. Detecting trend and seasonal changes in satellite image time series. Remote Sens. Environ. 2010, 114, 106-115.

35. Verbesselt, J.; Hyndman, R.; Zeileis, A.; Culvenor, D. Phenological change detection while accounting for abrupt and gradual trends in satellite image time series. Remote Sens. Environ. 2010, 114, 2970-2980.

36. Cleveland, R.B.; Cleveland, W.S.; McRae, J.E.; Terpenning, I. STL: A Seasonal-Trend Decomposition Procedure Based on Loess. J. Off. Stat. 1990, 6, 3-73.

37. Griesbauer, H.; Green, D.S.; O’Neill, G.A. Using a spatial temporal climate model to assess population-level Douglas-fir growth sensitivity to climate change across large climatic gradients in British Columbia, Canada. For. Ecol. Manag. 2011, 261, 589-600.

38. Matusick, G.; Ruthrof, K.; Brouwers, N.C.; Dell, B.; Hardy, G. Sudden forest canopy collapse corresponding with extreme drought and heat in a mediterranean-type forest in southwestern Australia. Eur. J. For. Res. 2012, 132, 497-510.

39. Raupach, M.R.; Briggs, P.R.; Haverd, V.; King, E.A.; Paget, M.; Trudinger, C.M. Australian Water Availability Project (AWAP): CSIRO Marine and Atmospheric Research Component: Final Report for Phase 3, Bureau of Meteorology and CSIRO, 2009. Available online: http://www.cawcr.gov.au/publications/technicalreports/CTR_013.pdf (accessed on 12 May 2011).

40. McDougal, K.L.; Hardy, G.; Hobbs, R.J. Comparison of colonisation of Phytophthora cinnamomi in detached stem tissue of Eucalyptus marginata in relation to site disease status. Australas. Plant. Pathol. 2007, 36, 498-500.

41. Heddle, E.M.; Loneragan, O.W.; Havel, J.J. Vegetation complexes of the darling system. In: Atlas of Natural Resources: Darling System, Perth: Dept. of Conservation and Environment; Nedlands, W.A.: distributed by University of Western Australia Press, 1980.

42. Williams, K.; Mitchell, D. Jarrah Forest 1 (JF1- Northern Jarrah Forest subregion): A Biodiversity Audit of Western Australia's 53 Biogeographical Subregions in 2002, Perth, 2002.

43. Koch, J.M.; Samsa, G.P. Restoring Jarrah Forest Trees after Bauxite Mining in Western Australia. Restor. Ecol. 2007, 15, 17-25.

44. ESRI, ArcGIS Desktop: Release 10, Environmental Systems Research Institute: Redlands, CA, USA, 2011. http://www.esri.com/software/arcgis/arcgis10 (accessed 4 June 2013)

45. Spot Image. Preprocessing levels and location accuracy, 2010 Available online: http://www.astrium-geo.com/files/pmedia/public/r454_9_preprocessing_levels_sept2010.pdf (accessed 4 June 2013)

46. EXELIS, ENVI EX Desktop: Release 1, Excelis Visual Information Solutions, Inc.: Boulder, Colorado, 2011.

http://www.exelisvis.com/Support/HelpArticlesDetail/TabId/219/ArtMID/900/ArticleID/5234/52 34.aspx (accessed 4 June 2013)

47. FAO Forest Resources Assessment WP 33: FRA 2000 ON DEFINITIONS OF FOREST AND FOREST CHANGE, Rome, 2000. Available online at http://www.fao.org/docrep/006/ad665e/ad665e00.htm (accessed 4 June 2013) 
48. Stewart, J.B.; Rickards, J.E.; Bordas, V.M.; Randall, L.; Thackway, R. Ground Cover Monitoring for Australia - Establishing a Coordinated Approach to Ground Cover Mapping. In Proceedings of Workshop Proceedings, 2011. Canberra, Australia, 23-24 November 2009; Australian Government Australian Bureau of Agricultural and Resource Economics (ABARES), Canberra, March 2009.

49. Van Dijk, A.I.J.M.; Renzullo, L.J. Water resource monitoring systems and the role of satellite observations. Hydrol. Earth Syst. Sci. 2011, 15, 39-55.

50. Prentice, C.I.; Sykes, M.T.; Cramer, W. A simulation model for the transient effects of climate change on forest landscapes. Ecol. Mod. 1993, 65, 51-70.

51. Priestley, C.H.B.; Taylor, R.J. On the Assessment of Surface Heat Flux and Evaporation Using Large-Scale Parameters. Mon. Weather Rev. 1972, 100, 81-92.

52. Middleton, N. World Atlas of Desertification, 2nd ed.; Middleton, N., Thomas, D.S.G., Eds.; Arnold: London, UK, 1997; p. 182.

53. Nix, H. A Biogeographic Analysis of Australian Elapid Snakes. In Atlas of Elapid Snakes of Australia; Australian Government Publishing Service: Canberra, Australia, 1986; pp. 4-15.

54. Hijmans, R.J.; Phillips, S.; Leathwick, J.; Elith, J. An $\{R\}$ Package for species distribution modelling, 2012. Available online: http://cran.r-project.org/web/packages/dismo/index.html (accessed on 4 June 2013).

55. Neilson, R.P.; Marks, D. A global perspective of regional vegetation and hydrologic sensitivities from climatic change. J. Veg. Sci. 1994, 5, 715-730.

56. Peel, D.R.; Pitman, A.J.; Hughes, L.A.; Narisma, G.T.; Pielke Sr, R.A. The impact of realistic biophysical parameters for Eucalypts on the simulation of the January climate of Australia. Environ. Mod. Softw. 2005, 20, 595-612.

57. Elith, J.; Graham, C.H.; Anderson, R.P.; Dudík, M.; Ferrier, S.; Guisan, A.; Hijmans, R.J.; Huettmann, F.; Leathwick, J.R.; Lehmann, A.; et al. Novel methods improve prediction of species' distributions from occurrence data. Ecography 2006, 29, 129-151.

58. Beaumont, L.J.; Hughes, L.; Poulsen, M. Predicting species distributions: Use of climatic parameters in BIOCLIM and its impact on predictions of species' current and future distributions. Ecol. Mod. 2005, 186, 251-270.

59. Renton, M.; Childs, S.; Standish, R.; Shackelford, N. Plant migration and persistence under climate change in fragmented landscapes: Does it depend on the key point of vulnerability within the lifecycle? Ecol. Mod. 2012, 249, 50-58.

60. Frelich, L.E.; Reich, P.B. Will environmental changes reinforce the impact of global warming on the prairie-forest border of central North America? Front. Ecol. Environ. 2010, 8, 371-378.

61. Wang, W.; Peng, C.; Kneeshaw, D.D.; Laroque, G.R.; Luo, Z. Drought-induced tree mortality: Ecological consequences, causes, and modelling. Environ. Rev. 2012, 20, 109-121.

62. Grassi, G.; Magnani, F. Stomatal, mesophyll conductance and biochemical limitations to photosynthesis as affected by drought and leaf ontogeny in ash and oak trees. Plant., Cell. Environ. 2005, 28, 834-849.

63. Limousin, J.M.; Misson, L.; Lavoir, A.V.; Martin, N.K.; Rambal, S. Do photosynthetic limitations of evergreen Quercus ilex leaves change with long-term increased drought severity? Plant., Cell. Environ. 2010, 33, 863-875. 
64. Wilson, K.B.; Baldocchi, D.; Hanson, P. Quantifying stomatal and non-stomatal limitations to carbon assimilation resulting from leaf aging and drought in mature deciduous tree species. Tree Physiol. 2000, 20, 787-797.

65. Chaves, M.M. Effects of Water Deficits on Carbon Assimilation. J. Exp. Bot. 1991, 42, 1-16.

66. Chaves, M.M.; Maroco, J.P.; Pereira, J.S. Understanding plant responses to drought — from genes to the whole plant. Funct. Plant. Biol. 2003, 30, 239.

67. Misson, L.; Limousin, J.M.; Rodriguez, R.; Letts, M.G. Leaf physiological responses to extreme droughts in Mediterranean Quercus ilex forest. Plant. Cell. Environ. 2010, 33, 1898-1910.

68. McDowell, N. Mechanisms linking drought, hydraulics, carbon metabolism, and vegetation mortality. Plant Physiol. 2011, 155, 1051-1059.

69. McDowell, N.G.; Beerling, D.J.; Breshears, D.D.; Fisher, R.A.; Raffa, K.F.; Stitt, M. The interdependence of mechanisms underlying climate-driven vegetation mortality. Trends Ecol. Evol. 2011, 26, 523-532.

70. Galmés, J.; Medrano, H.; Flexas, J. Photosynthetic limitations in response to water stress and recovery in Mediterranean plants with different growth forms. N. Phytol. 2007, 175, 81-93.

71. Granier, A.; Reichstein, M.; Bréda, N.; Janssens, I.A.; Falge, E.; Ciais, P.; Grünwald, T.; Aubinet, M.; Berbigier, P.; Bernhofer, C.; et al. Evidence for soil water control on carbon and water dynamics in European forests during the extremely dry year: 2003. Agric. For. Meteorol. 2007, 143, 123-145.

72. Haldimann, P.; Gallé, A.; Feller, U. Impact of an exceptionally hot dry summer on photosynthetic traits in oak (Quercus. pubescens) leaves. Tree Physiol. 2008, 28, 785-795.

73. Luo, H. Mature semiarid chaparral ecosystems can be a significant sink for atmospheric carbon dioxide. Glob. Chang. Biol. 2007, 13, 386-396.

74. Knight, D.H.; Wallace, L.L. The Yellowstone Fires: Issues in Landscape. Ecol. BioSci 1989, 39, 700-706.

(C) 2013 by the authors; licensee MDPI, Basel, Switzerland. This article is an open access article distributed under the terms and conditions of the Creative Commons Attribution license (http://creativecommons.org/licenses/by/3.0/). 